\title{
The effect of heat treatment on the microstructure and functional properties of whey protein from goat milk
}

\author{
Xuan Zhao, ${ }^{1} \odot$ Ming Cheng, ${ }^{2}$ Xuexi Zhang, ${ }^{1}$ Xiangying Li, ${ }^{1} \oplus$ Di Chen, ${ }^{1} \oplus$ Yusi Qin, ${ }^{1}$ Jianmin Wang, ${ }^{3}$ \\ and Cunfang Wang ${ }^{1 *}$ (iD \\ ${ }^{1}$ College of Food Science and Engineering, Qilu University of Technology (Shandong Academy of Sciences), Jinan, China, 250353 \\ ${ }^{2}$ Qingdao Research Institute of Husbandry and Veterinary, Qingdao, China, 266100 \\ ${ }^{3}$ College of Animal Science and Veterinary Medicine, Shandong Agricultural University, Taian, China, 271018
}

\section{ABSTRACT}

This work investigated the effects of thermal processing methods commonly used in the dairy industry and prolonged treatment at different temperatures on the denaturation, microstructure, and functional properties of whey proteins (WP) from goat milk. The complete denaturation of WP was observed in goat milk treated at $85^{\circ} \mathrm{C}$ for $30 \mathrm{~min}$, and at a higher temperature $\left(>85^{\circ} \mathrm{C}\right)$, a considerable amount of WP was easily denatured. The low temperature, long time treatment had the least effect on the secondary structure, whereas ultra-high temperature treatment had the greatest effect, and the amount of regular structures decreased gradually with prolonged time. The most serious morphological damage occurred after treatment at $85^{\circ} \mathrm{C}$ for 30 min, which was consistent with the denaturation results. This result indicated that the denaturation degree, particle size, surface hydrophobicity, and microstructure had a strong influence on the functional properties of WP from goat milk after heat treatment. The heat treatment of goat milk at $65^{\circ} \mathrm{C}$ for 30 min and $85^{\circ} \mathrm{C}$ for $15 \mathrm{~s}$ increased the particle size, turbidity, zeta potential, and surface hydrophobicity of WP, and these increases ensured that the WP had a good emulsifying activity index, water-holding capacity, oil-holding capacity, foaming capacity, and foam stability. This study simulated the heat treatment conditions used in actual production, aiming to provide a theoretical basis for industry.

Key words: goat milk, whey protein, heat treatment, microstructure, functional properties

Received July 5, 2019.

Accepted October 18, 2019.

*Corresponding author: cunfangwang@163.com

\section{INTRODUCTION}

Recently, goat milk has become popular with consumers because of its low lactose content, high protein content, high calcium content, and high proportion of more digestible fatty acids compared with cow milk (Haenlein, 2004; Kalyankar et al., 2016; Chen et al., 2018). In cow and goat milk, no significant difference was found in the total protein content. However, a significantly lower amount was found of $\mathrm{a}_{\mathrm{S} 1} \mathrm{CN}$, which only exists in the casein micelle, and a higher concentrate of $\beta-\mathrm{CN}+\kappa-\mathrm{CN}$ in the serum phase. Therefore, goat milk can be better digested in the human body compared with cow milk, which was found to be a main reason why the goat milk is relatively better in terms of nutritional utilization. As for mineral composition, goat milk is very similar to cow milk with regard to the content of $\mathrm{Na}, \mathrm{Fe}, \mathrm{Zn}$, and $\mathrm{Mb}$, but has higher amounts of $\mathrm{Ca}, \mathrm{K}, \mathrm{Mg}, \mathrm{P}, \mathrm{Cl}$, and $\mathrm{Mn}$. The good digestion of goat milk for humans also lies in its short- and medium-chain fatty acids. Results have shown both a higher mineral content and better utilization in goat milk (Ceballos et al., 2009). A comparative study stated that the hydrophobic sites on the micelle surface of goat milk were greater than those of sheep milk (Yuksel et al., 2012). Differences are also present in various goat breeds. The 2 most common methods used to analyze the differences are SDS-PAGE and reversed-phase HPLC. The ratio of $\alpha-L A / \beta-L G$ presented a significant difference between sheep and goat WP in Greek breeds (Moatsou et al., 2005). However, a similarity between the 2 types of milk is that the content of $\alpha_{\mathrm{S1}^{-}} \mathrm{CN}$ is very small (Costa et al., 2014). Heat treatment is one of the most common processing methods in the dairy industry and can kill microorganisms in raw milk, which can ensure food safety and extend the shelf life of products (McKinnon et al., 2009; Claeys et al., 2013). However, heat treatment can cause chemical changes, such as interactions among proteins, and many studies have indicated that 
the aggregation of whey protein (WP)/casein is one of the main chemical changes that occur during heat treatment in goat milk (Sharma and Dalgleish, 1993; Vasbinder and Kruif, 2003). In addition, WP aggregates are composed of $\alpha-\mathrm{LA}$ and $\beta-\mathrm{LG}$ in the serum phase (Donovan and Mulvihill, 1987). Native $\beta$-LG exists as a dimer, containing 2 disulfide bonds and 1 free thiol group buried inside the molecule (Wijayanti et al., 2014). $\alpha$-Lactalbumin is stabilized by 4 disulfide bonds and lacks a thiol group, so $\alpha$-LA cannot form aggregates unless in the presence of free thiol groups (Permyakov and Berliner, 2000). The order of ease of irreversible WP was $\mathrm{Ig}>$ serum albumin $(\mathbf{S A})>$ lactoferrin $(\mathbf{L f})>\beta$-LG $>\alpha$-LA of caprine milk. The $\alpha$-LA and $\beta$-LG unfold at 66 and $75^{\circ} \mathrm{C}$, respectively (Clark et al., 1981). Upon reaching the denaturation temperature, the molecular structure of WP will be destroyed, and the disulfide bonds and thiol group will be exposed and available for reactions. Then, WP tends to associate with $\mathrm{\kappa}$-CN in serum ( $\mathrm{Li}$ et al., 2014a), forming $\beta$-LG aggregates and $\beta$-LG/ $\alpha$-LA dimers and aggregates by $-\mathrm{SH} / \mathrm{S}-\mathrm{S}$ interchange interactions. Serum albumin, whose denaturation temperature is $66^{\circ} \mathrm{C}$, can also associate with $\alpha$-LA in a similar way (Havea et al., 2000; Considine et al., 2007). Some reports have clarified the pathways of $\beta-\mathrm{LG} / \alpha-\mathrm{LA}$ aggregation and WP/ $\mathrm{CN}$ complex formation, which occur through $-\mathrm{SH} / \mathrm{S}-\mathrm{S}$ interactions (Vasbinder and Kruif, 2003). Similar reactions were also found in goat milk; according to Felipe et al. (1997), the WP of goat milk was treated at $83^{\circ} \mathrm{C}$ for $1 \mathrm{~min}$ and then loaded to SDS-PAGE without adding 2-mercaptoethanol. As a result, WP and $\kappa$-CN did not appear in the running gel, but their larger size aggregates were found in the stacking gel, which proved that WP/ $\mathrm{\kappa}-\mathrm{CN}$ complex was formed by disulfide bonds (Felipe et al., 1997). Furthermore, the soluble WP/CN complex has been proven to reduce the gel time of yak milk and improve the structure of yogurt gel (Xu et al., 2015). In this regard, WP can be effectively used as an ingredient in the food industry because of its outstanding interfacial properties and is usually used as an emulsifying and foaming agent (Anandharamakrishnan et al., 2008; Nicorescu et al., 2008).

Previous studies have mainly focused on the heat treatment of WP below $100^{\circ} \mathrm{C}$, and little information is available on the microstructure and functional properties of WP from goat milk after pasteurization and UHT treatment. Moreover, the molecular changes caused by heat treatment may have a positive or negative influence on the functional properties of WP (McSweeney et al., 2004). Therefore, it is necessary to clarify how heat treatment affects denaturation and the subsequent changes in the functional properties of WP from goat milk. This study aims to determine the denaturation extent of WP from goat milk during thermal processing methods commonly used in dairy production and under prolonged treatment at different temperatures, as well as the changes in the WP microstructure and functional properties, to improve the utilization of WP by simulating the processing conditions in the food industry.

\section{MATERIALS AND METHODS}

\section{Collection and Preparation of Goat Milk Samples}

Fresh goat milk samples were collected from Laoshan goats at the Qingdao Aote Goat Breeding Farm in Shandong Province, China. All the goats were in the mid stage of lactation, showed no signs of acute mastitis or other clinical diseases, and were milked by machine at $1000 \mathrm{~h}$. All milk samples were transferred on ice to the laboratory. The unheated samples served as the control group (CG), and other samples were treated according to Figure 1 referring to the heating method of Chen et al. (2019). The pasteurization/UHT group consisted of low temperature, long time (LTLT) at $65^{\circ} \mathrm{C}$ for $30 \mathrm{~min}$ (PG1), HTST at $85^{\circ} \mathrm{C}$ for $15 \mathrm{~s}$ (PG2), ultrapasteurization at $125^{\circ} \mathrm{C}$ for $4 \mathrm{~s}$ (PG3), and UHT at $135^{\circ} \mathrm{C}$ for $4 \mathrm{~s}$ (UG). The $\mathbf{S 1}, \mathbf{S 2}, \mathbf{S 3}, \mathbf{S 4}$, and $\mathbf{S} 5$ treatments were $65^{\circ} \mathrm{C}$ for $15 \mathrm{~s}, 65^{\circ} \mathrm{C}$ for $1 \mathrm{~min}$, $65^{\circ} \mathrm{C}$ for $5 \mathrm{~min}, 65^{\circ} \mathrm{C}$ for $10 \mathrm{~min}$, and $65^{\circ} \mathrm{C}$ for $15 \mathrm{~min}$, respectively. The E1, E2, E3, E4, and E5 treatments were $85^{\circ} \mathrm{C}$ for $1 \mathrm{~min}, 85^{\circ} \mathrm{C}$ for $5 \mathrm{~min}, 85^{\circ} \mathrm{C}$ for $10 \mathrm{~min}$, $85^{\circ} \mathrm{C}$ for $15 \mathrm{~min}$, and $85^{\circ} \mathrm{C}$ for $30 \mathrm{~min}$, respectively. The $\mathbf{O} 1$ and Q1 treatments were $105^{\circ} \mathrm{C}$ for $15 \mathrm{~s}$ and $125^{\circ} \mathrm{C}$ for $15 \mathrm{~s}$, respectively. The samples were heated by laboratory miniature pasteurizer and laboratory UHT sterilizer (YC-02, Pilotech Company, Shanghai, China). The minimum pasteurization capacity is 1,000 $\mathrm{mL}$, the temperature of pasteurization is 30 to $90^{\circ} \mathrm{C}$, the accuracy of heating and temperature control is $\pm 1^{\circ} \mathrm{C}$, and the external tap water or ice water is used for cooling. The minimum amount of UHT sterilization is $3 \mathrm{~L}$, the highest sterilization temperature is $150^{\circ} \mathrm{C}$, and the cooling temperature is $20^{\circ} \mathrm{C}$.

\section{Preparation of Whey Protein and SDS-PAGE}

All samples were centrifuged at $4^{\circ} \mathrm{C}, 2,149 \times g$ for 15 min and the upper fat were discarded, then the skim milk was collected (Palmquist and Jenkins, 2003). The skim milk, adjusted by $10 \%$ acetic acid to $\mathrm{pH} 4.10$, was centrifuged at $4^{\circ} \mathrm{C}, 1,986 \times g$ for $15 \mathrm{~min}$, and then the supernatant was WP (Recio et al., 1997). The powder WP was obtained by vacuum freeze drying and stored 
at $-20^{\circ} \mathrm{C}$ in a refrigerator for the determination of micellar structure and functional properties.

The SDS-PAGE was performed according to the method of Sun et al. (2014). The WP powder samples were dissolved in water to a solution of $2 \mathrm{mg} / \mathrm{mL}$. The WP solution was added to water in a 1:1 volume ratio and mixed evenly. Then $10 \mu \mathrm{L}$ were loaded onto the gels composed by $12 \%$ separation gel concentration and $5 \%$ concentration gel, with $1 \mathrm{~mm}$ of gel thickness, and electrode buffer consisted of SDS buffer ( $\mathrm{pH}$ 8.3) and Tris-Gly solution (Macklin Biochemical, Shanghai, China). Electrophoresis was carried out for approximately $3.5 \mathrm{~h}$ at $4^{\circ} \mathrm{C}$, and gels were stained for 2 to $4 \mathrm{~h}$ with Coomassie Brilliant Blue R-250 (Biotopped Technology Company, Beijing, China) and decolored until a clear background was achieved. The electropherograms were scanned with an optical density scanner, the scanned images were processed and analyzed in Lane 1D gel analysis software (Sagecreation Company, Beijing, China), and the relative optical density (IOD) of each protein band on the map was analyzed. The IOD was calculated as follows: integral optical density (IOD) = $\Sigma(\mathrm{OD} \times$ area $)$, where OD is the optical density.

\section{Determination of the Denaturation of WP by HPLC}

Skimmed samples were centrifuged at $4^{\circ} \mathrm{C}, 20,893 \times$ $g$ for $60 \mathrm{~min}$, and serum phases were collected to be HPLC samples. A C4 column $(250 \mathrm{~mm} \times 4.6 \mathrm{~mm}, 5$ $\mu \mathrm{m}, 300 \AA$ ) was used in an RP-HPLC Agilent 1100 (Agilent Technologies, Santa Clara, CA); the detection wavelength was $214 \mathrm{~nm}$; the flow rate was $0.8 \mathrm{~mL} / \mathrm{min}$; the column temperature was $30^{\circ} \mathrm{C}$; and the injection volume was $20 \mu \mathrm{L}$. Ultrapure water containing $0.1 \%$ TFA and acetonitrile containing $0.1 \%$ TFA were used as mobile phases A and B, respectively. Gradient elution: 0 to 12 min, $\mathrm{B}$ concentration of 30 to $36 \% ; 12$ to $30 \mathrm{~min}, \mathrm{~B}$ concentration of $36 \%$; 30 to $45 \mathrm{~min}, \mathrm{~B}$ concentration of 36 to $40 \%$; 45 to $60 \mathrm{~min}$, B concentration of 40 to $43 \%$; 60 to 61 min, B concentration of 43 to $100 \%$; 61 to $63 \mathrm{~min}$, B concentration of $100 \%$; 63 to $68 \mathrm{~min}, \mathrm{~B}$ concentration of 100 to $30 \%$; 68 to $80 \mathrm{~min}, \mathrm{~B}$ concentration of $30 \%$. The denaturation degree of WP was calculated by the formula (M1 - M2)/M1, where M1 is the quantity of undenatured WP in fresh milk and M2 is the quantity of undenatured WP in heated milk.

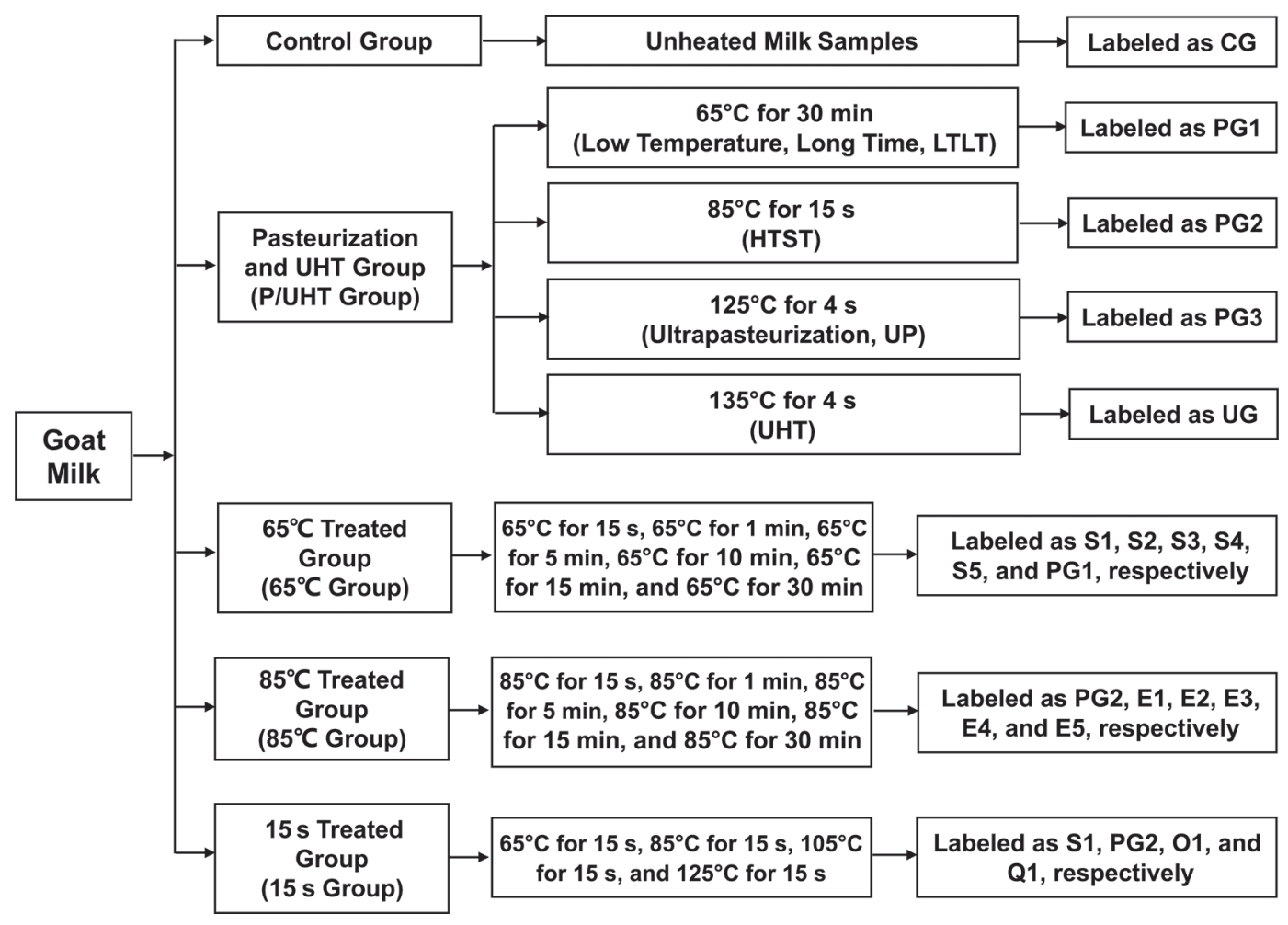

Figure 1. Workflow for sample collection and preparation. 


\section{Determination of the Secondary Structure of WP}

Fourier-transform infrared spectroscopy was used to measure the secondary structure of the WP. The WP powder made by freeze drying and potassium bromide were uniformly mixed at a ratio of 1:150, subjected to tableting treatment, and then tested over time. The test parameters were set as follows: 10 scans, resolution $4 \mathrm{~cm}^{-1}$, and scan range from 4,000 to $400 \mathrm{~cm}^{-1}$. The infrared spectra obtained by scanning were compared; the characteristic amide I protein band was selected for analysis, and the secondary structure of the protein was further characterized by infrared desorption. Spectral acquisition, peak finding, and basic analysis were performed using Omnic 8.2 software (Thermo Fisher Scientific, Waltham, MA). Multipeak fitting was performed using Peakfit 4.12 software (Systat Software Inc., San Jose, CA) until the residual was minimal $\left(\mathrm{R}^{2}\right.$ $>0.999)$.

\section{Determination of the Particle Size, Zeta Potential, Turbidity, and Surface Hydrophobicity of WP}

The particle size and zeta potential were measured by Zetasizer Nano ZS90 (Malvern Panalytical Ltd., Malvern, UK), and the WP solutions were diluted to $10 \mathrm{mg} / \mathrm{mL}$ before measurement, as described by Lamb et al. (2013). The parameters were as follows: particle refractive index 1.450 , particle absorption rate 0.001 , dispersant refractive index 1.330, dispersant absorption rate 0.8872 , and water as dispersant. The turbidities of the WP solutions $(2 \mathrm{mg} / \mathrm{mL})$ were determined by the absorbance at $633 \mathrm{~nm}$ using a UV spectrophotometer and a cell with a 1.0-cm path length (Partschefeld et al., 2007).

The surface hydrophobicity of the WP was measured by fluorescence intensity as an indicator. Twenty milliliters of WP $(0.6 \mathrm{mg} / \mathrm{mL})$ was added to $100 \mu \mathrm{L}$ of 8-aniline-1-naphthalenesulfonic acid, shaken, and allowed to stand for $3 \mathrm{~min}$ for fluorescence scanning. The scanning parameters were set as follows: excitation wavelength: $368 \mathrm{~nm}$; emission wavelength: 390 to 600 $\mathrm{nm}$; scanning speed: $300 \mathrm{~nm} / \mathrm{min}$; and slit: $5 \mathrm{~nm}$.

\section{Scanning Electron Microscopy of WP}

A volume of $5 \mu \mathrm{L}$ WP solution $(100 \mu \mathrm{g} / \mathrm{mL})$ was placed on a clean silicon chip and dried naturally. The silicon chip was placed in an evaporating dish, $50 \mu \mathrm{L}$ of prepared $2.5 \%$ glutaraldehyde solution was dropped onto the silicon wafer, and the wafer was sealed with wrap film and fixed at $4^{\circ} \mathrm{C}$ overnight. A series of clean- ing and gradient dehydration operations were then performed to dry the wafer. After coating with gold, the samples were observed by ASU8010 cold field emission scanning electron microscopy as described by Yang et al. (2014).

\section{Determination of the Functional Properties of WP}

The emulsifying activity index (EAI) and the emulsion stability (ES) were measured according to the method of Pearce and Kinsella (1978). The EAI and ES were calculated using the following formulas:

$$
\begin{aligned}
\mathrm{EAI}= & \left(2 \times 2.303 \mathrm{~A}_{0} \times \mathrm{N} \times 10^{-4} /(\varphi \mathrm{L} \rho),\right. \\
& \operatorname{ES}(\%)=\mathrm{A}_{1} / \mathrm{A}_{0} \times 100 \%,
\end{aligned}
$$

where $A_{0}$ and $A_{1}$ are the absorbance of a blank sample and a mixed sample of WP and soybean oil, respectively; $\mathrm{N}$ is the dilution factor of the emulsion; $\varphi$ is the volume fraction of the oil phase; $\mathrm{L}$ is the cuvette diameter $(\mathrm{cm})$; and $\rho$ is the concentration of the WP solution. A volume of $2 \mathrm{~mL}$ of WP solution $(10 \mathrm{mg} /$ $\mathrm{mL}$ ) was placed in a $10-\mathrm{mL}$ glass cylinder with a stopper. The initial height of the solution was recorded as $\mathrm{V}_{0}$, the cylinder was manually agitated for $1 \mathrm{~min}$, and then the height of the foam was immediately recorded as $V_{1}$. The height of the foam was recorded again after $5 \mathrm{~min}$, and this value was named $\mathrm{V}_{2}$. The foaming capacity (FC) and foam stability (FS) were calculated as follows:

$$
\begin{gathered}
\mathrm{FC}=\frac{\mathrm{V}_{1}-\mathrm{V}_{0}}{\mathrm{~V}_{0}}, \\
\mathrm{FS}=\left(\mathrm{V}_{2}-\mathrm{V}_{0}\right) /\left(\mathrm{V}_{1}-\mathrm{V}_{0}\right) .
\end{gathered}
$$

The WP $(\mathrm{m}=0.1 \mathrm{~g})$ was accurately weighed in a 10$\mathrm{mL}$ centrifuge tube, and the weight of the WP and centrifuge tube was recorded as $\mathrm{m}_{1}$. Five milliliters of distilled water or soybean oil was added, and then the tube was mixed thoroughly in vortex mixer for $1 \mathrm{~min}$, allowed to stand at room temperature for $1 \mathrm{~h}$, and centrifuged at 1,986 $\times g$ for $30 \mathrm{~min}$ at room temperature. The supernatant was discarded, and the pellet was dried at $37^{\circ} \mathrm{C}$ for $30 \mathrm{~min}$. The weight of the pellet and centrifuge tube was recorded as $\mathrm{m}_{2}$. The water-holding capacity (WHC) and oil-holding capacity (OHC) were calculated as follows:

$$
\mathrm{WHC}(\mathrm{OHC})=\left(\mathrm{m}_{2}-\mathrm{m}_{1}\right) / \mathrm{m} \text {. }
$$




\section{Statistical Analysis}

Data were analyzed by one-way ANOVA using SPSS software version 22 (IBM Corp., Armonk, NY). Significant differences between means were indicated when $P<0.05$, and Origin 8.5 (OriginLab Corporation, Northampton, MA) was used to plot and report the data.

\section{RESULTS AND DISCUSSION}

\section{Profile of Proteins in WP from Heat-Treated Goat Milk}

Goat milk is characterized by a very low heat stability, which could be related to compositional factors (Morgan et al., 2001). As Figure 2 shows, $\beta$-LG and $\alpha$-LA were the 2 most abundant components, accounting for approximately $70 \%$ of the total amount of WP. Changes in these 2 proteins could affect the properties of WP. Compared with the results for CG, the relative content of $\beta$-LG increased significantly $(P<0.05)$ in PG1 and reached a maximum in PG2. A previous study demonstrated the same change trend in $\beta-\mathrm{LG}$ from goat milk subjected to different heat treatments, according to liquid chromatography-MS and ELISA analysis (Chen et al., 2019). This may be because native $\beta$-LG changes from dimers to monomers at approximately $72^{\circ} \mathrm{C}$ : with increased heating time and temperature, the process became more obvious, and the $-\mathrm{SH}$ inside was exposed. Meanwhile, $\kappa-\mathrm{CN}$ gradually dissociated from casein micelles, and then $\beta$-LG could form a complex with $\kappa-\mathrm{CN}$ via $-\mathrm{SH} / \mathrm{S}-\mathrm{S}$ interchange. Further heating would result in a decrease in the $\mathrm{pH}$ of the solution, the $\mathrm{pH}$ of fresh goat milk was about 6.57 , whereas the $\mathrm{pH}$ of LTLT, HTST, UP, and UHT decreased to 6.52, $6.55,6.50$, and 6.46 , respectively. The previous research suggested that the heat-induced interaction of $\beta$-LG with $\kappa$-casein is of minor importance at natural $\mathrm{pH}$, but is promoted at more elevated $\mathrm{pH}$ (Morgan et al., 2001). Also, the $\beta-\mathrm{LG} / \mathrm{CN}$ would in turn combine with the surface of the casein micelles, which would result in a decrease in the serum content of the 2 proteins. In contrast to $\beta$-LG, $\alpha$-LA decreased slightly in PG1 but maintained its original content in PG2 and increased significantly $(P<0.05)$ in PG3 and UG. The heat stability of $\alpha$-LA was due to the binding of $\mathrm{Ca}^{2+}$ inside the molecule; therefore, the denaturation temperature was raised by $40^{\circ} \mathrm{C}$. A previous study also suggested that the content of $\alpha$-LA was maintained at 22 to $25 \%$ with HTST and UHT treatment (Qi et al., 2015). However, IgG, SA, and Lf, which are sensitive to heat, decreased significantly after HTST and UHT treatment $(P<$
0.05) compared with the values for CG, which is similar to the results of a previous study (Shimo et al., 2015).

\section{Denaturation Degree of WP Under Different Processing Conditions}

As shown in Figure 3C, under the instantaneous $(<15 \mathrm{~s})$ heating conditions, significant differences were observed among the treatments at 85, 105, 125, and $135^{\circ} \mathrm{C}$. High-temperature treatment could result in a large amount of WP denaturation. At the same heating time, a significant difference was observed between S3 $\left(65^{\circ} \mathrm{C} / 5 \mathrm{~min}\right)$ and $\mathrm{E} 2\left(85^{\circ} \mathrm{C} / 5 \mathrm{~min} ; P<0.05\right)$. There was also a significant difference between PG1 $\left(65^{\circ} \mathrm{C} / 30\right.$ $\min )$ and $\mathrm{E} 5\left(85^{\circ} \mathrm{C} / 30 \mathrm{~min}\right)$. The change trend in the denaturation degree of WP in PG1 and E5 was similar to that in S3 and E2. That is, with increased heating temperature, the denaturation degree of goat milk WP
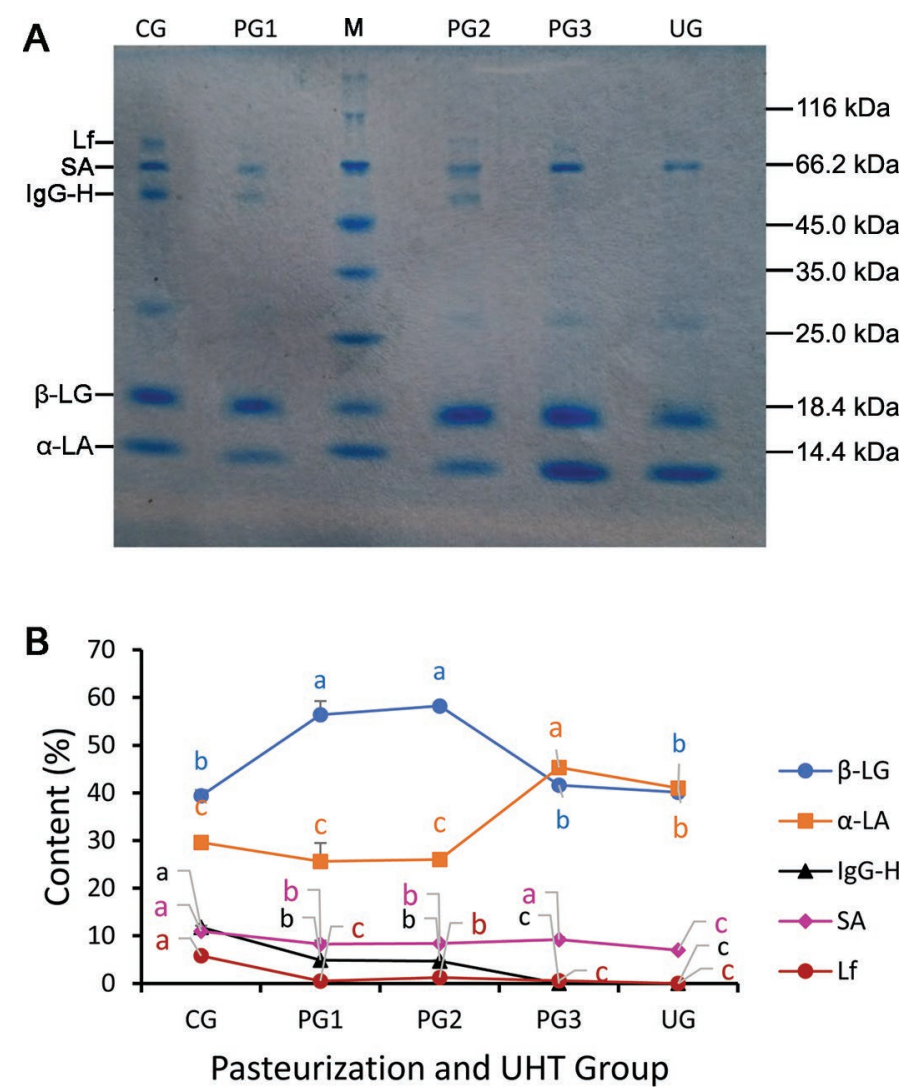

Figure 2. The SDS-PAGE profile (A) and content of protein components in whey protein (WP) of heat-processed goat milk (B). For $A$, lane $M$ is the marker. The unheated samples served as the control group (CG), and other samples were treated according to Figure 1 referring to the heating method of Chen et al. (2019). Lf = lactoferrin; $\mathrm{SA}=$ serum albumin. For panel $\mathrm{B}$, values of each group not sharing the same letters $(\mathrm{a}-\mathrm{c})$ are significantly different $(P<0.05)$, and error bars represent SD. 
increased significantly. A previous study reported that the levels of denaturation of $\beta$-LG were generally higher than those for $\alpha$-LA during HTST processing of model infant milk formula solutions (Joyce et al., 2017). The $\alpha-\mathrm{LA}, \mathrm{SA}$, and $\operatorname{IgG}$ lost their natural conformation at approximately 64 to $66^{\circ} \mathrm{C}$, whereas $\beta$-LG unfolded at $72^{\circ} \mathrm{C}$. Considering the low proportion of $\mathrm{SA}$ and $\mathrm{IgG}$ in WP and the relatively strong heat resistance of $\alpha$-LA, little denaturation occurred at $65^{\circ} \mathrm{C}$. However, camel serum albumin showed substantial denaturation with increased temperature during heat treatment (Genene et al., 2019). One study suggested also that WP from goat milk were more denatured than those from cow milk in samples heated at temperatures higher than $75^{\circ} \mathrm{C}$ (Montilla et al., 1995). The WP denaturation reached $72.3 \%$ under treatment at $85^{\circ} \mathrm{C}$ for $5 \mathrm{~min}$ in this study, whereas a previous study reported a value of more than $81.2 \%$ under treatment at $85^{\circ} \mathrm{C}$ for $2 \mathrm{~min}$ (Joyce et al., 2017). The highest observed denaturation degree was the complete denaturation of WP under treatment at $85^{\circ} \mathrm{C}$ for $30 \mathrm{~min}$, and a similar result was reported by Ruffin et al. (2014). However, the results showed that a considerable amount of WP was easily denatured at high temperatures $\left(>85^{\circ} \mathrm{C}\right)$. Similarly, more WP would be denatured after a longer time at the same temperature. The reactive groups would be exposed when the denaturation temperature of each protein is reached ( $\mathrm{Li}$ et al., 2014b).

\section{Changes in the Secondary Structure of WP During Processing Under Different Conditions}

After heat treatment, the most obvious changes occurred from 3,600 to $3,100 \mathrm{~cm}^{-1}$ and 1,700 to $1,600 \mathrm{~cm}^{-1}$ (Figure 4, amide I band). The infrared spectrum of WP in CG had an obvious characteristic absorption peak at approximately $3,310 \mathrm{~cm}^{-1}$, which indicated abundant intermolecular and intramolecular hydrogen bonding in the WP. In the PG treatments and UG, from 3,600 to $3,100 \mathrm{~cm}^{-1}$, different degrees of blueshift were observed, which represented damage to the molecular conformation of WP; this damage may have been caused by the destruction of hydrogen bonds that stabilized the conformation. The amide I band $\left(1,700-1,600 \mathrm{~cm}^{-1}\right)$ is a sensitive region for protein secondary structure changes. The $\mathrm{CG}$ absorption peak was at $1,647.2 \mathrm{~cm}^{-1}$, and little change occurred in UG, whereas a blueshift occurred in PG2 and PG3, which was essentially consistent with the changes in the bands from 3,600 to $3,100 \mathrm{~cm}^{-1}$.

Multipeak fitting of the deconvoluted spectra showed that 9 to 10 subpeaks were obtained for each sample, and the fitting results are shown in Figure 4. The re-
A

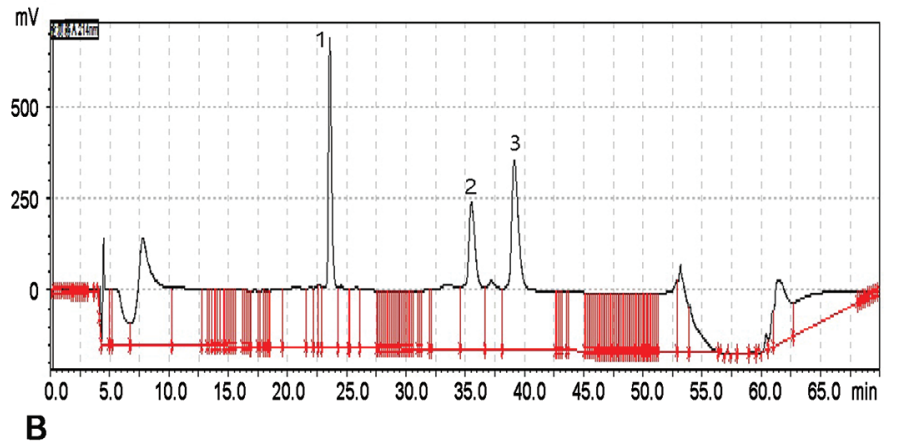

B
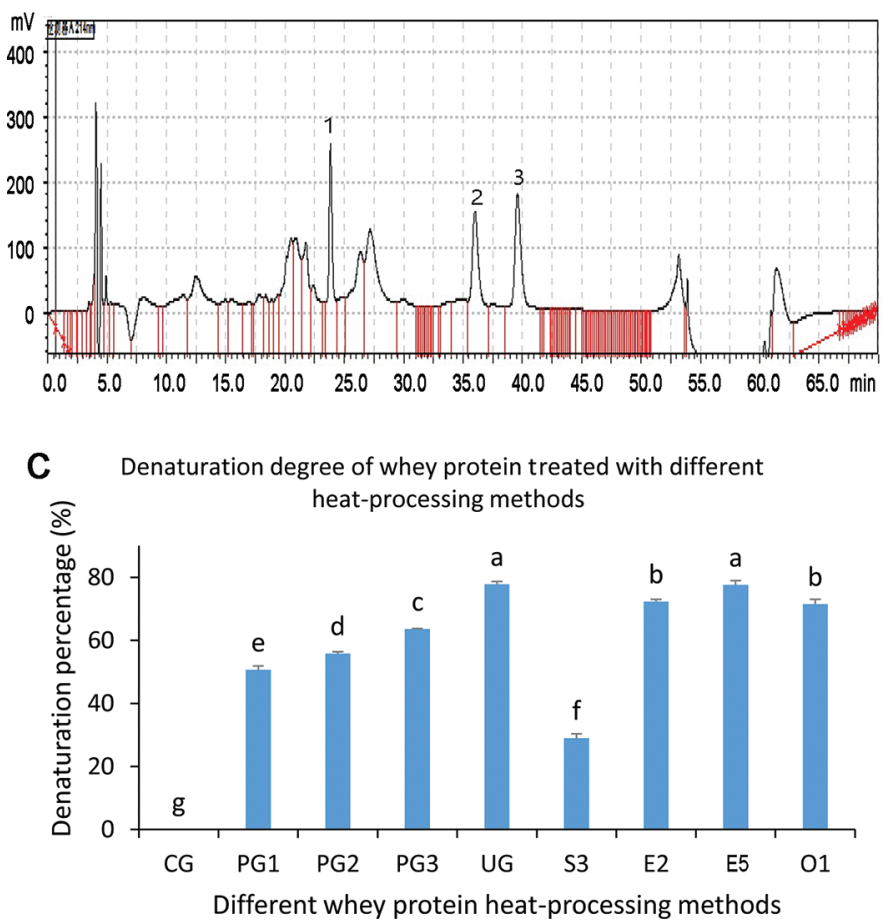

Figure 3. High-performance liquid chromatography of standards (A) and samples (B) and denaturation degree of whey protein (WP) from goat milk under different heat-processing conditions $(\mathrm{C})$. Peaks 1,2 , and 3 in $\mathrm{A}$ and $\mathrm{B}$ represent $\alpha-\mathrm{LA}, \beta-\mathrm{LG} \mathrm{A}$, and $\beta-\mathrm{LG} \mathrm{B}$, respectively. The unheated samples served as the control group (CG), and other samples were treated according to Figure 1 referring to the heating method of Chen et al. (2019). Different letters (a-g) indicate a significant difference $(P<0.05)$ among the different processing treatments, and error bars represent SD.

lationships between each subpeak in the amide I band and the secondary conformational structures were as follows: 1,650 to $1,660 \mathrm{~cm}^{-1}$ represented $\alpha$-helix structures, 1,600 to $1,640 \mathrm{~cm}^{-1}$ and 1,682 to $1,700 \mathrm{~cm}^{-1}$ represented $\beta$-sheet structures, 1,661 to $1,681 \mathrm{~cm}^{-1}$ represented $\beta$-turn structures, and 1,641 to $1,650 \mathrm{~cm}^{-1}$ represented unordered structures (Barth, 2007). The relative contents of secondary structures in WP are displayed in Figure 5. In the PG samples and UG, the total contents of $\alpha$-helix and $\beta$-sheet structures were reduced 

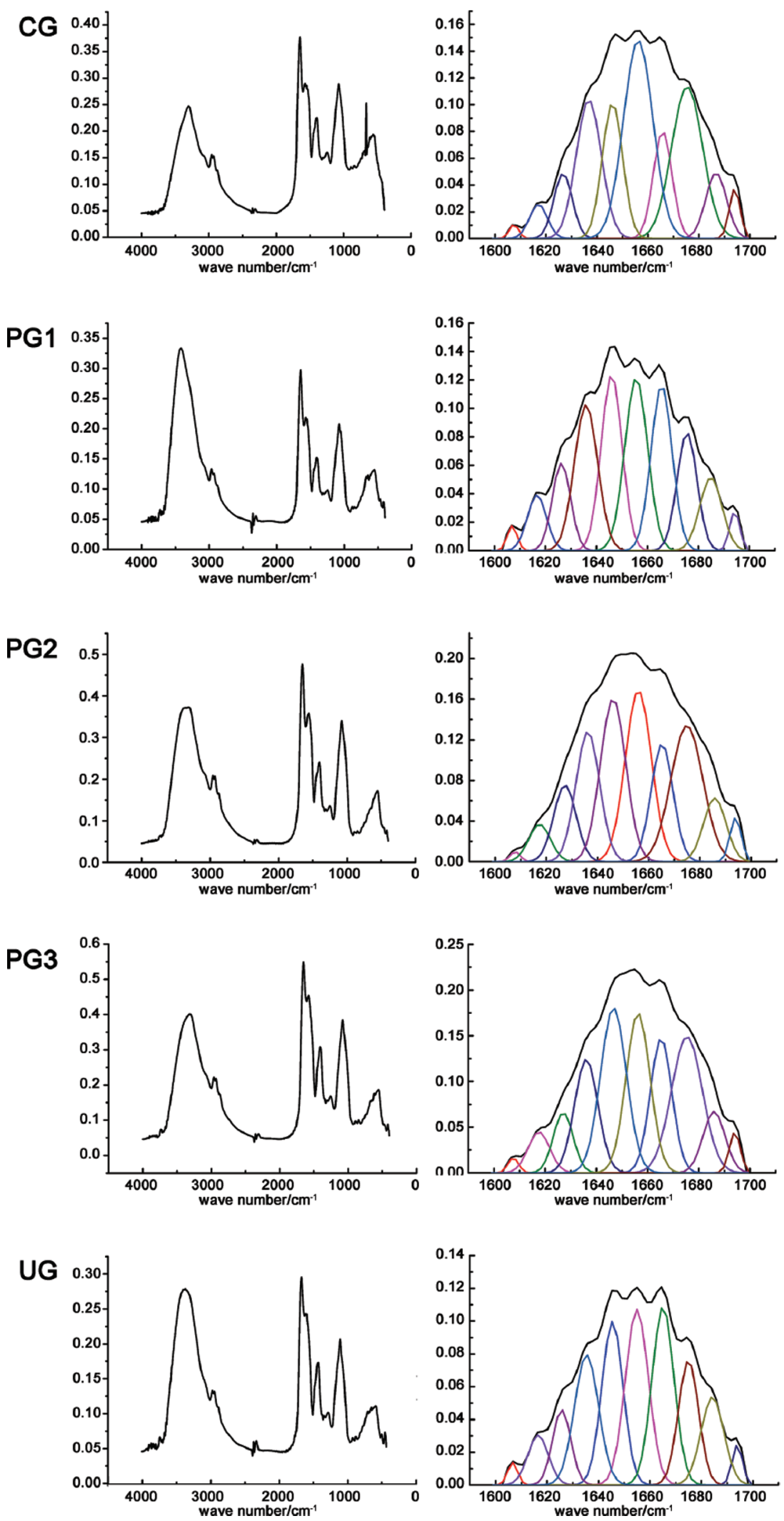

Figure 4. Secondary structure original spectra and amide I band multimodal fitting spectra of whey protein (WP) from heat-processed goat milk. The unheated samples served as the control group (CG), and other samples were treated according to Figure 1 referring to the heating method of Chen et al. (2019). 

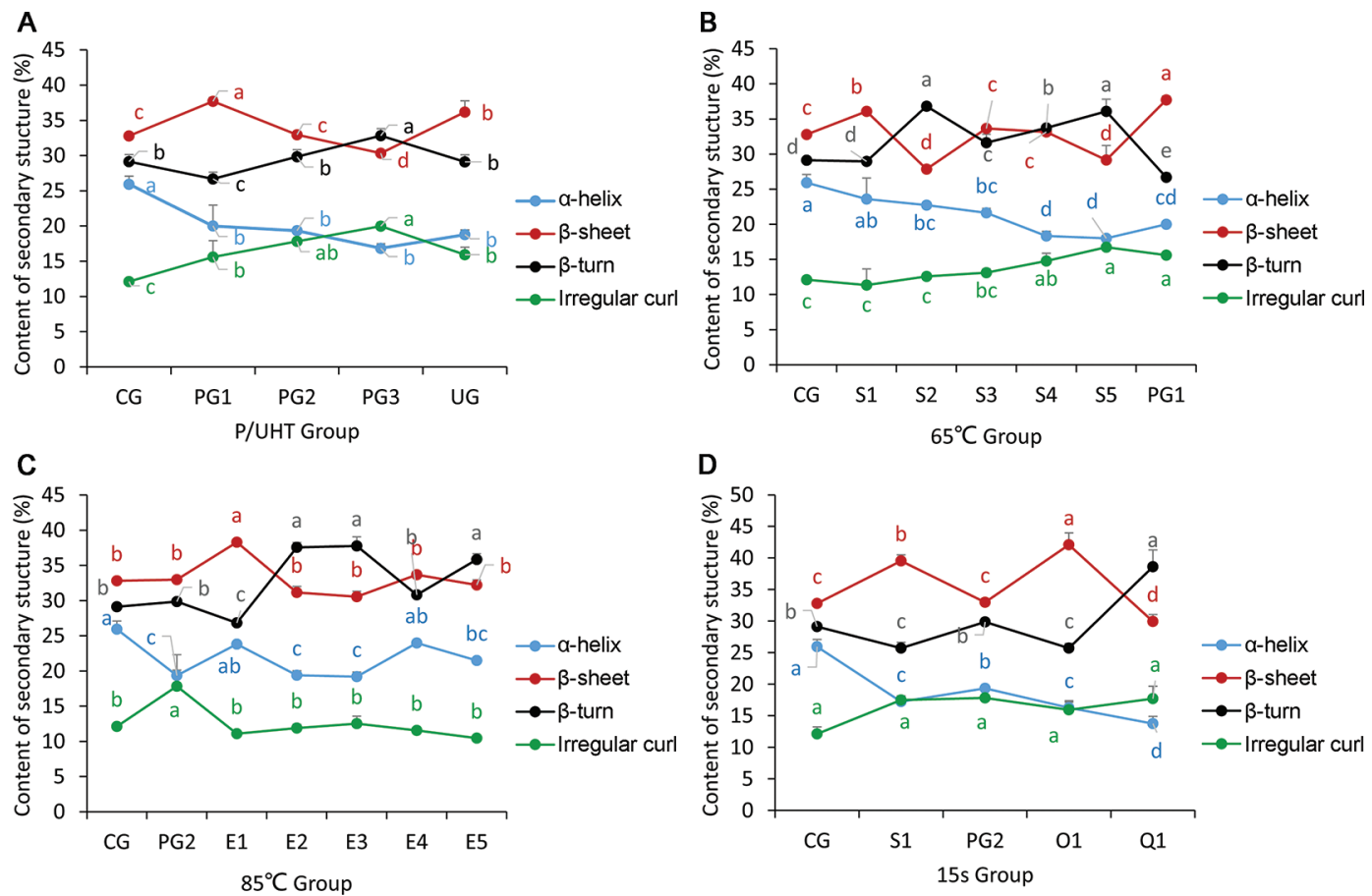

Figure 5. The secondary structure content of whey protein (WP) from heat-processed goat milk. Different letters (a-e) indicate a significant difference $(P<0.05)$ among the different processing treatments. P/UHT group = pasteurization and UHT group, and error bars represent SD. The unheated samples served as the control group (CG), and other samples were treated according to Figure 1 referring to the heating method of Chen et al. (2019).

to different degrees, and irregular structures, including $\beta$-turn and unordered structures, increased (Figure $5 \mathrm{~A})$. Previous research has shown that $\alpha$-helices and $\beta$-sheets are regular secondary structures in WP and that $\alpha$-helices are the most stable (Parks and Player, 2007). The LTLT treatment had the least effect on secondary structure, whereas UG had the greatest effect. In the $65^{\circ} \mathrm{C}$ group, the regular-structure content decreased gradually with prolonged time, and significant decreases occurred in S4, S5, and PG1 (Figure 5B). Similar results were found in the $85^{\circ} \mathrm{C}$ group. In the instantaneous treatment group, the irregular-structure content increased with increasing temperature, which was essentially consistent with the results for the denaturation rate of WP. The results indicated that the secondary structure of WP was damaged to varying degrees and the damage was worsened with high temperature and prolonged heating time.

\section{Morphological Analysis of WP During Processing Under Different Conditions}

The WP of fresh goat milk exhibited a regular globular structure with slight aggregation, as shown in Figure 6 (CG). The WP in PG1 maintained this globular structure, and the particle size increased slightly. Some globular-structured WP changed into flake-structured WP, probably due to $\alpha$-LA and SA aggregation via -SH/S-S interchange interactions under LTLT treatment. More obvious changes were observed in PG3 and UG, and almost all globular structures were destroyed and changed into a flake state. This was due to the much higher temperature of UP and UHT treatment, which destroyed intramolecular hydrogen bonds and disulfide bonds. Then, rapid and considerable denaturation occurred, which involved $\beta-\mathrm{LG}$ aggregation, $\beta-\mathrm{LG} / \alpha-\mathrm{LA}$ aggregation, and $\beta-\mathrm{LG} / \kappa-\mathrm{CN}$ complexation via $-\mathrm{SH} / \mathrm{S}-\mathrm{S}$ interchange. It has been suggested that denatured WP films are more stretchable due to covalent cross-linking (Khem et al., 2016).

Compared with PG1, no clear changes in the globular structure of $\mathrm{S} 1$ were observed in $\mathrm{S} 3\left(65^{\circ} \mathrm{C} / 5 \mathrm{~min}\right)$, whereas in the $85^{\circ} \mathrm{C} / 5$ min group, the WP morphology possessed a less globular structure, and the particle size was observed to increase significantly. The most serious morphological damage occurred in $\mathrm{E} 5\left(85^{\circ} \mathrm{C} / 30\right.$ min). The WP was almost completely changed into a flake state, and significant aggregation was observed, which was consistent with the high denaturation rate of $78 \%$ in this study. Several globular WP could still 
be observed in $\mathrm{O} 1\left(105^{\circ} \mathrm{C} / 15 \mathrm{~s}\right)$. However, more serious destruction was observed in O1 and UG. Therefore, during transient heating, a greater change would occur to the surface topography of WP with higher temperatures.

\section{Changes in the Particle Size, Turbidity, Zeta Potential, and Surface Hydrophobicity of WP During Processing Under Different Conditions}

As Figure 7A shows, the particle size of PG3 increased significantly $(P<0.05)$ to a maximum of $301 \mathrm{~nm}$ compared with that of $\mathrm{CG}$, while the particle size of UG decreased significantly $(P<0.05)$. In the $65^{\circ} \mathrm{C}$-treated group, the particle size increased significantly except for in S1, and no significant change was observed among the other 5 samples. In the $85^{\circ} \mathrm{C}$-treated group, the particle size increased significantly $(P<0.05)$ in PG2 and E2 and then decreased with prolonged time. In the 15-s treated group, PG2 increased significantly, reached a maximum, and then decreased. There was a common trend among the 4 treated groups: with increasing temperature and prolonged time, the particle size rose first and then fell. The temperature of $65^{\circ} \mathrm{C}$ is close to the denaturation temperature of $\alpha-\mathrm{LA}$ and SA, and $\alpha-\mathrm{LA} /$ SA aggregation resulted in an increase in the PG1 particle size (Akkerman et al., 2016). $\beta$-Lactoglobulin changed into monomers and unfolded at $85^{\circ} \mathrm{C}$, which is higher than its denaturation temperature. The $-\mathrm{SH}$ inside $\beta$-LG became exposed and then reacted with $\mathrm{S}-\mathrm{S}$ contained in $\alpha-\mathrm{LA}$ and $\kappa-\mathrm{CN}$ in serum, and $\mathrm{WP} /$ CN complexes appeared as the particle size increased (Wijayanti et al., 2014). With increasing temperature, when the level of protein polymerization had reached a certain extent, the aggregates failed to stabilize in the serum phase and then precipitated, and the particle size decreased (Genene et al., 2019). According to the study of Giroux et al. (2018), the agglomerates of WP could

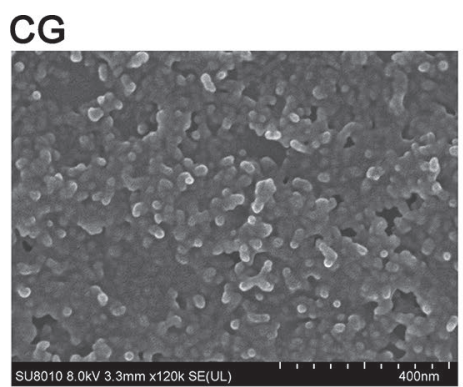

\$3
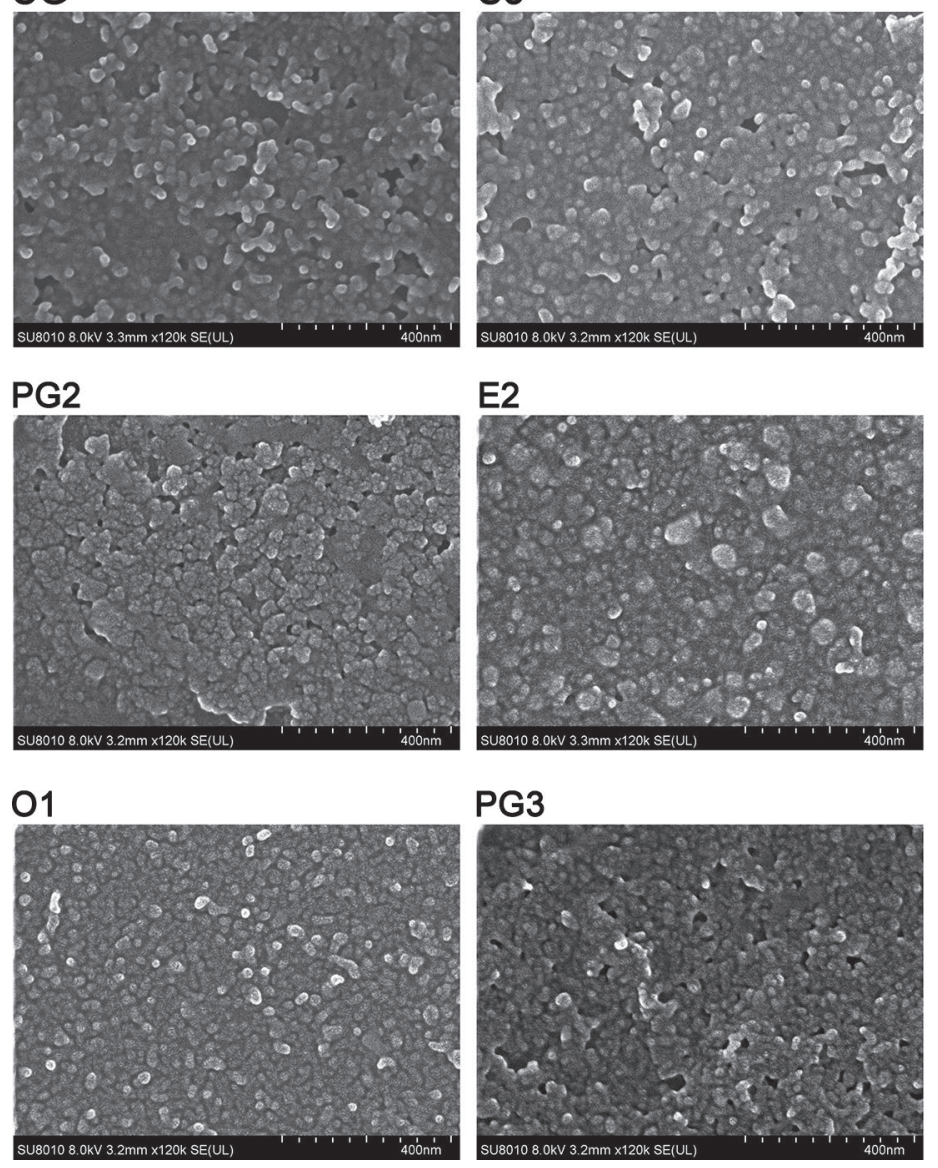

PG3

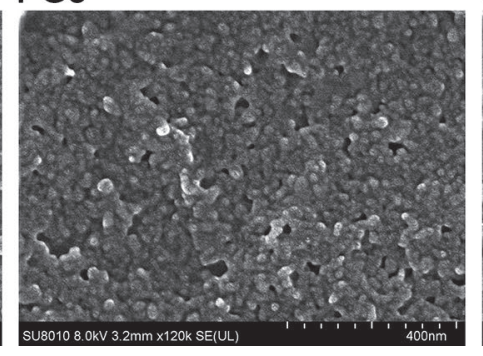

PG1

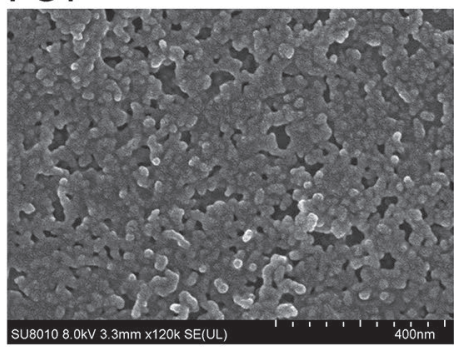

E5

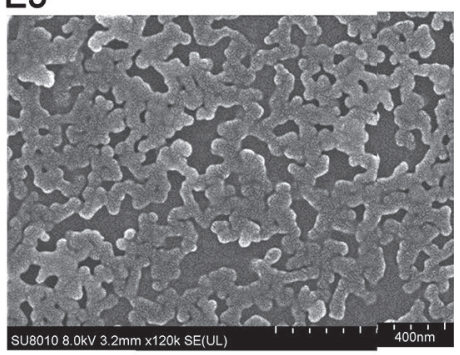

UG

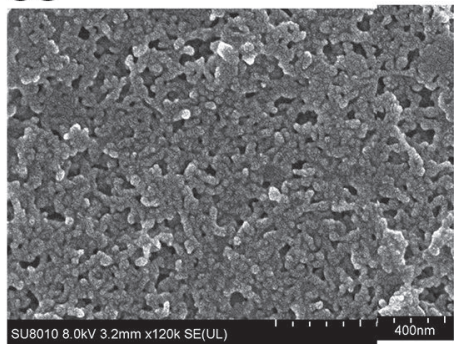

Figure 6. Scanning electron micrographs of whey protein (WP) from heat-processed goat milk $(\times 120,000)$. The unheated samples served as the control group (CG), and other samples were treated according to Figure 1 referring to the heating method of Chen et al. (2019). 
improve the productivity of artisanal cheese plants by significantly increasing cheese yield without negative effects on the flavor of cheese. In this study, the turbidity was related to the molecular size of the WP. The change trend was similar to that of particle size (Figure 7B). Only the zeta potential of WP treated at $85^{\circ} \mathrm{C}$ had a significant difference, whereas that of other groups had no significant change (Figure 7C). It turned out that less turbid WP soluble aggregates of cow milk may be used to increase shelf life by reducing protein precipitation in beverages (Ryan et al., 2013). In this study, the turbidity of LTLT and HTST samples was significantly lower than other treated samples. The zeta potential of WP treated at $85^{\circ} \mathrm{C} / 15 \mathrm{~min}$ and $85^{\circ} \mathrm{C} / 30$ min increased significantly, which was essentially consistent with the change trend in particle size in the $85^{\circ} \mathrm{C}$ groups in this study. The larger the particle size was, the more aggregated the molecules. In addition, the intermolecular forces of WP during heating affect the stability of WP in the system (Zhang et al., 2016). In the $65^{\circ} \mathrm{C}$-treated group, no significant difference was observed. A temperature of $65^{\circ} \mathrm{C}$ would only destroy hydrogen bonds and block van der Waals forces, which would not have a strong impact on zeta potential.
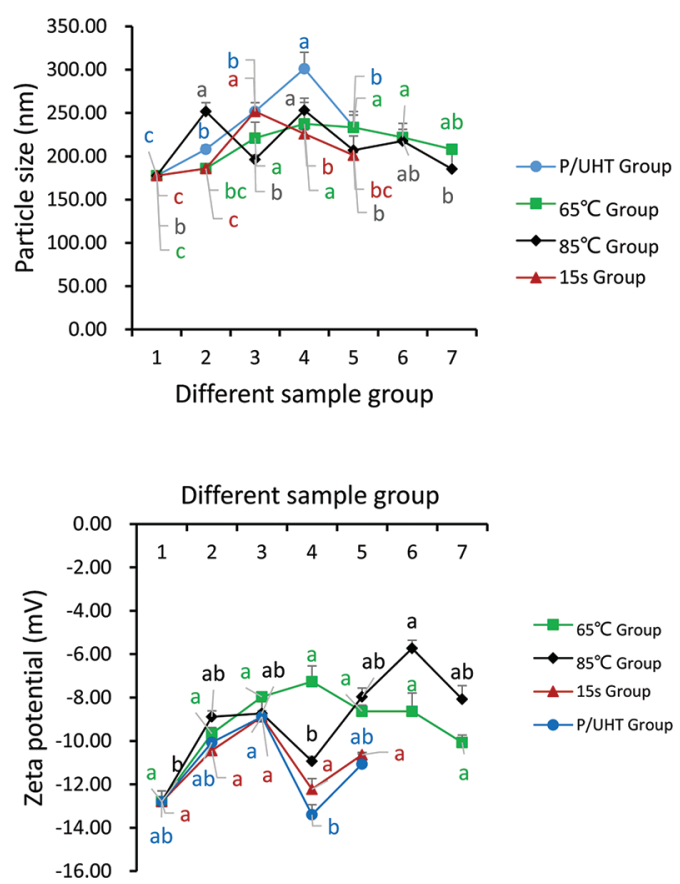

The hydrophilic residues and hydrophobic side chains of WP were in a relatively balanced state in CG. Compared with the results in $\mathrm{CG}$, the hydrophobicity of WP increased after heat treatment at $65^{\circ} \mathrm{C} / 30 \mathrm{~min}$ and $85^{\circ} \mathrm{C} / 15 \mathrm{~s}$ but decreased significantly after heat treatment at $125^{\circ} \mathrm{C} / 4 \mathrm{~s}$ and $135^{\circ} \mathrm{C} / 4 \mathrm{~s}$ (Figure $7 \mathrm{D}$ ). The LTLT and HTST treatment resulted in more unfolding of WP molecules, thus exposing more hydrophobic groups from the cores of the globular proteins, thereby leading to an increase in surface hydrophobicity (Kim et al., 2005). Hydrophobic interactions would dominate again when the peptide chains are stretched to a certain extent and then reaggregated, resulting in a decrease in surface hydrophobicity. In the $65^{\circ} \mathrm{C}$-heated group, the fluorescence intensity increased differently. The WP did not denature completely, but its peptide chains were gradually stretched at $65^{\circ} \mathrm{C}$. The $85^{\circ} \mathrm{C}$-treated group changed significantly $(P<0.05)$, and the fluorescence intensity increased and then decreased with increasing processing time. During continuous heating, reactions due to hydrophobic forces occurred, the WP aggregated, and fewer hydrophobic residues were exposed to water. A similar trend appeared in the 15 s-treated group. This study indicated that the heat treatment of goat
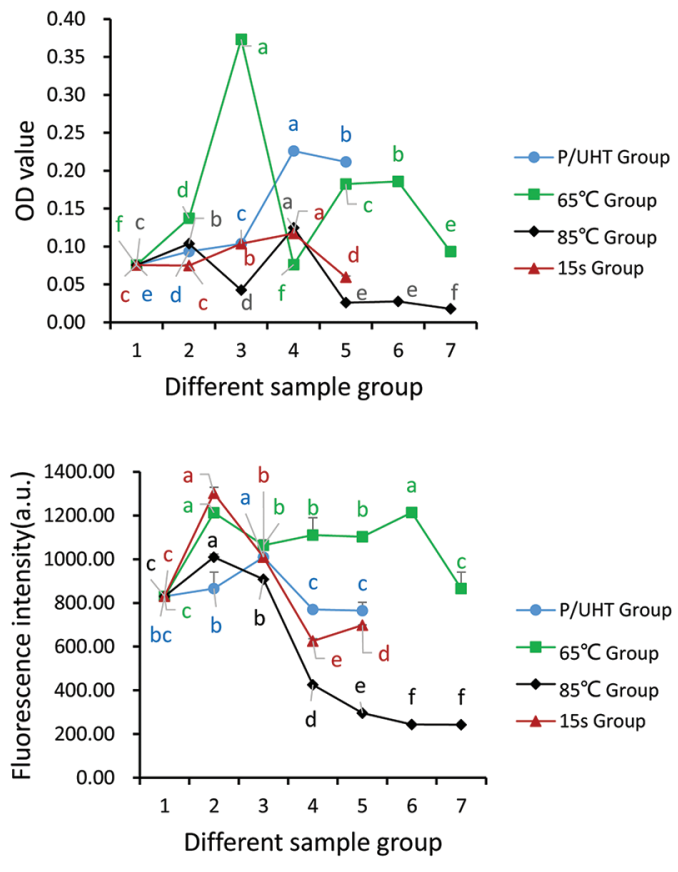

Figure 7. Changes in particle size, turbidity, zeta potential, and surface hydrophobicity of whey protein (WP) subjected to different processing treatments. The unheated samples served as the control group (CG), and other samples were treated according to Figure 1 referring to the heating method of Chen et al. (2019). For the pasteurization and UHT (P/UHT) group, 1 to 5 denote CG, PG1, PG2, PG3, and UG, respectively; for the $65^{\circ} \mathrm{C}$ group, 1 to 7 denote CG, S1, S2, S3, S4, S5, and PG1, respectively; for the $85^{\circ} \mathrm{C}$ group, 1 to 7 denote CG, PG2, E1, E2, E3, E4, and E5, respectively; and for the $15 \mathrm{~s}$ group, 1 to 5 denote CG, S1, PG2, O1, and Q1, respectively. Different letters (a-f) indicate a significant difference $(P<0.05)$ among different processing treatments, and error bars represent SD. 
milk at 65 and $85^{\circ} \mathrm{C}$ increased the surface hydrophobicity of WP. A similar result has previously been noted: preheating WPI increased the surface hydrophobicity and viscosity of WPI dispersions (Ruffin et al., 2014).

\section{Changes in the Functional Properties of WP During Processing Under Different Conditions}

Emulsifying activity index is related to the surface hydrophobicity of molecules, and ES is related to the flexibility of proteins (Dickinson, 1997). As Figure $8 \mathrm{~A}$ shows, EAI was increased significantly $(P<0.05)$ with the 4 heat treatments and reached a maximum in PG1. Under strong heating conditions $\left(65^{\circ} \mathrm{C}\right.$ for 30 min), the WP was completely unfolded, and a high EAI of the WP was observed; this result can be explained by the increase in surface hydrophobicity and decrease in particle size of WP from goat milk heated at $65^{\circ} \mathrm{C}$ for $30 \mathrm{~min}$. This result occurred because WP unfolds and exposes the hydrophobic groups from the cores of the globular proteins (Croguennec et al., 2004; Ruffin et al., 2014). At higher temperatures, hydrophobic interactions became the dominant force, and the WP aggregated again, resulting in a decrease in EAI. It was also revealed that thermal processing at temperatures ranging from 60 to $90^{\circ} \mathrm{C}$ for $1,000 \mathrm{~s}$ had negative effects on EAI due to the failure of the large protein aggregates to absorb the fat droplets (Millqvist-Fureby et al., 2001). In terms of ES, the formation of protein complexes led to poor adsorption after heat treatment. Moreover, increased unfolding of proteins resulted in an increased flexibility of protein molecules, thus affecting the behavior of the interfacial adsorbed protein layer and the steric interactions between droplets and enhancing emulsion stability (Ruffin et al., 2014). The overall trend of EAI and ES showed a weak inverse relationship; that is, a higher EAI was associated with a lower ES under the same processing conditions (Figure $8 \mathrm{~A}$ ). In addition, the high solubility of the WP complexes caused by heat treatment contributed to the good emulsifying properties of the WP. As shown in Figure $8 \mathrm{~B}$, the WP samples from goat milk heated at $65^{\circ} \mathrm{C}$ for $30 \mathrm{~min}$ and $85^{\circ} \mathrm{C}$ for $15 \mathrm{~s}$ had a good WHC and $\mathrm{OHC}$, respectively. The trend of $\mathrm{OHC}$ was similar to that of surface hydrophobicity. This indicated that LTLT should be applied to ensure an excellent WHC of WP and avoid the whey precipitation of yogurt. This study showed that pasteurization could improve emulsification performance, while the UHT process was not suitable for the processing of WP as an emulsifier. It also has been proved the soluble heat-induced $\mathrm{WP} / \kappa-$ CN complex could increase WHC and firmness of yak yogurt (Xu et al., 2015). Whey protein is one of the most common foaming agents. Foaming of WP can be evaluated by FC and FS. Foaming capacity is related to the volume of gas introduced into a WP solution, and FS is determined by the rate of foam disappearance over time (Nicorescu et al., 2008). From Figure 8C to $8 \mathrm{~F}$, we can see that the same results were obtained for $\mathrm{FC}$ and FS as for EAI, WHC, and $\mathrm{OHC}$ in this study: the WP of goat milk heated at $65^{\circ} \mathrm{C}$ for $30 \mathrm{~min}$ and $85^{\circ} \mathrm{C}$ for $15 \mathrm{~s}$ had a good FC and FS compared with those of goat milk samples from all other heat treatments. Figure $8 \mathrm{C}$ shows that both FC and FS in PG1 and PG2 increased significantly $(P<0.05)$, which can be explained by the stretching of protein peptide chains after heat treatment and the exposure of hydrophobic groups previously buried inside the protein structure, which could increase hydrophobic interactions and enhance the formation of foam (Lee et al., 1992). It has been reported that polymers can enhance FS due to their contribution to film viscosity and elasticity (Nicorescu et al., 2008). At higher temperatures, the formation of aggregates resulted in fewer proteins available to stabilize the gas-liquid interface (Richert et al., 1974; Bals and Kulozik, 2003). Therefore, when UP and UHT hydrophobic interactions dominated again, the WP reaggregated and failed to absorb to the gas-liquid interface, in accordance with the significant decrease in FC and FS $(P<0.05)$ in this study. With HTST, UP, and UHT treatment, the existence of large protein complexes made the WP unstable in solution, and FS decreased significantly $(P<0.05)$. From this, we can deduce that pasteurization improved foaming performance, whereas UHT treatment substantially damaged foaming performance.

\section{CONCLUSIONS}

In this study, the effects of thermal processing methods commonly used in the dairy industry and prolonged treatment at different temperatures on the denaturation, microstructure, and functional properties of WP from goat milk were investigated in detail. The results showed that the denaturation degree, particle size, surface hydrophobicity, and microstructure had a strong influence on the functional properties of WP from goat milk after heat treatment. Heat treatment of goat milk at $65^{\circ} \mathrm{C}$ for $30 \mathrm{~min}$ and $85^{\circ} \mathrm{C}$ for $15 \mathrm{~s}$ increased the particle size, turbidity, zeta potential, and surface hydrophobicity of WP, and these increases ensured that the WP had a good EAI, WHC, OHC, FC, and FS. Due to its functional properties, WP is commonly used as a food additive in the food industry. In this study, LTLT and HTST could be used preferentially in industry to improve the properties of WP, which could be 

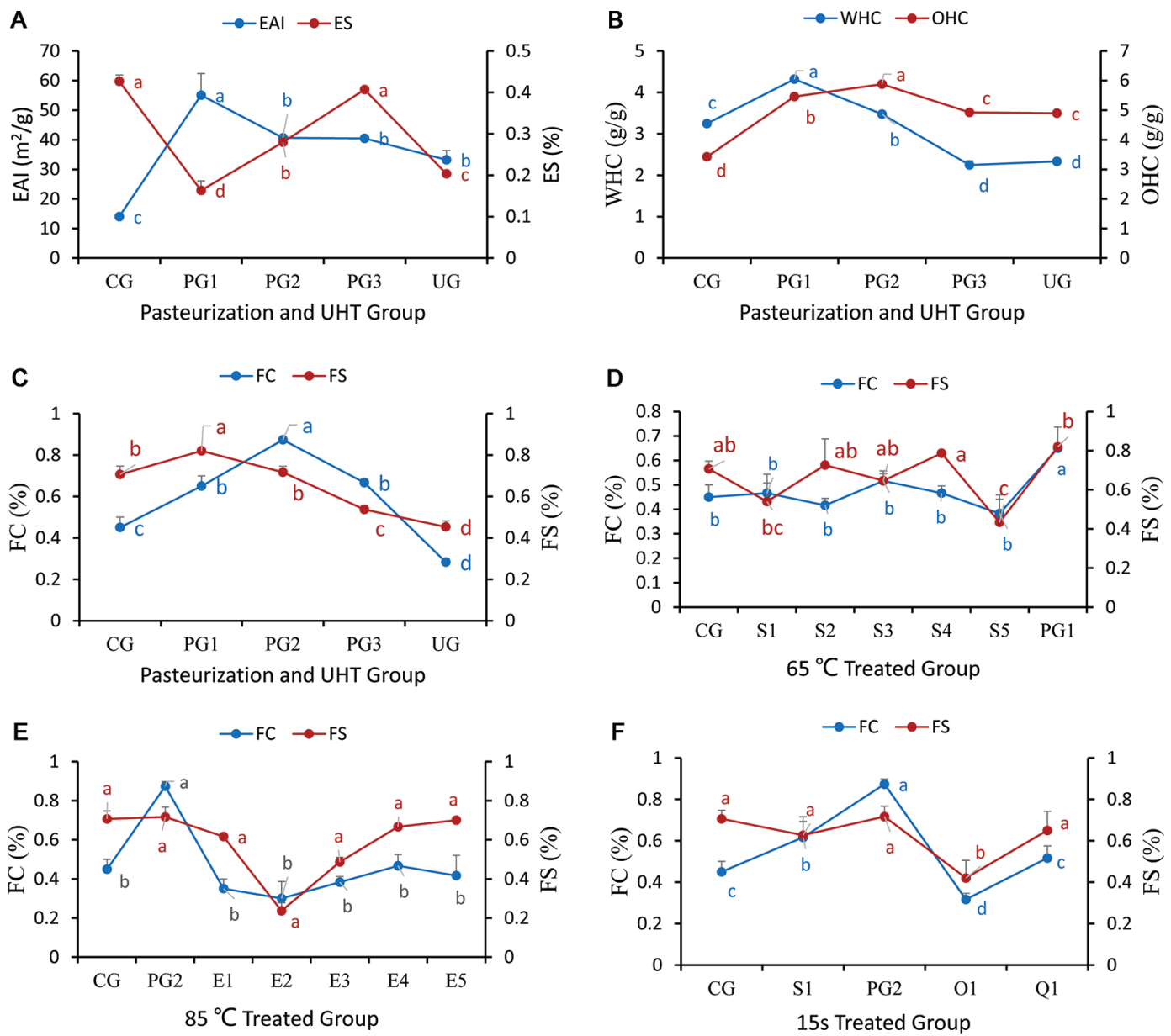

Figure 8. Changes in the functional properties of whey protein (WP) from heat-processed goat milk. Different letters (a-d) indicate a significant difference $(P<0.05)$ among different processing treatments, and error bars represent SD. EAI $=$ emulsifying activity index; ES $=$ emulsion stability; WHC = water-holding capacity; OHC = oil-holding capacity; FC = foaming capacity; FS = foam stability. The unheated samples served as the control group (CG), and other samples were treated according to Figure 1 referring to the heating method of Chen et al. (2019).

a key advancement for the dairy industry. This study simulated the heat treatment conditions used in actual production, aiming to provide a theoretical basis for industry. Further research is needed on the application of goat milk.

\section{ACKNOWLEDGMENTS}

Funds for this work were provided by the Key Research and Development Program of Shandong Province (2019YYSP025) and the National Natural Science Foundation of China (31501501). The authors declare that they have no competing interests.

\section{REFERENCES}

Akkerman, M., V. Rauh, M. Christensen, L. Johansen, M. Hammershöj, and L. Larsen. 2016. Effect of heating strategies on whey protein denaturation-Revisited by liquid chromatography quadrupole time-of-flight mass spectrometry. J. Dairy Sci. 99:152-166. https:/ /doi.org/10.3168/jds.2015-9924.

Anandharamakrishnan, C., C. D. Rielly, and A. G. F. Stapley. 2008 Loss of solubility of $\alpha$-lactalbumin and $\beta$-lactoglobulin during the spray drying of whey proteins. Lebensm. Wiss. Technol. 41:270277. https://doi.org/10.1016/j.lwt.2007.03.004.

Bals, A., and U. Kulozik. 2003. Effect of pre-heating on the foaming properties of whey protein isolate using a membrane foaming apparatus. Int. Dairy J. 13:903-908. https://doi.org/10.1016/S0958 $-6946(03) 00111-0$.

Barth, A. 2007. Infrared spectroscopy of proteins. Biochim. Biophys. Acta 1767:1073-1101.

Ceballos, L. S., E. R. Morales, G. de la Torre Adarve, J. D. Castro, L. P. Martínez, and M. R. S. Sampelayo. 2009. Composition of goat and cow milk produced under similar conditions and analyzed by identical methodology. J. Food Compos. Anal. 22:322-329. https:/ /doi.org/10.1016/j.jfca.2008.10.020.

Chen, D., X. Li, X. Zhao, Y. Qin, C. Wang, and C. Wang. 2019. Comparative proteomics of goat milk during heated processing. Food Chem. 275:504-514. https://doi.org/10.1016/j.foodchem.2018.09 .129 .

Chen, D., X. Zhao, X. Li, J. Wang, and C. Wang. 2018. Milk compositional changes of Laoshan goat milk from partum up to 261 days postpartum. Anim. Sci. J. 89:1355-1363. https://doi.org/10 $.1111 /$ asj.13062. 
Claeys, L., S. Cardoen, G. Daube, J. De Block, K. Dewettinck, K. Dierick, L. De Zutter, A. Huyghebaert, H. Imberechts, P. Thiange, Y. Vandenplas, and L. Herman. 2013. Raw or heated cow milk consumption: Review of risks and benefits. Food Control 31:251-262. https://doi.org/10.1016/j.foodcont.2012.09.035.

Clark, A. H., D. H. Saunderson, and A. Suggett. 1981. Infrared and laser-Raman spectroscopic studies of thermally-induced globular protein gels. Int. J. Pept. Protein Res. 17:353-364.

Considine, T., H. A. Patel, S. G. Anema, H. Singh, and L. K. Creamer. 2007. Interactions of milk proteins during heat and high hydrostatic pressure treatments - A review. Innov. Food Sci. Emerg. Technol. 8:1-23. https://doi.org/10.1016/j.ifset.2006.08.003.

Costa, W. K. A., E. L. Souza, E. M. Beltrão-Filho, G. K. V. Vasconcelos, T. Santi-Gadelha, C. A. de Almeida Gadelha, O. L. Franco, and M. Magnani. 2014. Comparative protein composition analysis of goat milk produced by the Alpine and Saanen breeds in northeastern Brazil and related antibacterial activities. PLoS One 9:e93361. https://doi.org/10.1371/journal.pone.0093361.

Croguennec, T., B. T. O'Kennedy, and R. Mehra. 2004. Heat-induced denaturation/aggregation of -lactoglobulin A and B: Kinetics of the first intermediates formed. Int. Dairy J. 14:399-409. https:// doi.org/10.1016/j.idairyj.2003.09.005.

Dickinson, E. 1997. Properties of emulsions stabilized with milk proteins: Overview of some recent developments. J. Dairy Sci. 80:2607-2619. https://doi.org/10.3168/jds.S0022-0302(97)76218 -0 .

Donovan, M., and D. M. Mulvihill. 1987. Thermal denaturation and aggregation of whey proteins. Int. J. Food Sci. Technol. 11:87-100.

Felipe, X., M. Capellas, and A. J. R. Law. 1997. Comparison of the effects of high-pressure treatments and heat pasteurization on the whey proteins in goat's milk. J. Agric. Food Chem. 45:627-631. https://doi.org/10.1021/jf960406o.

Genene, A., E. B. Hansen, M. Eshetu, Y. Hailu, and R. Ipsen. 2019 Effect of heat treatment on denaturation of whey protein and resultant rennetability of camel milk. Lebensm. Wiss. Technol. 101:404-409. https://doi.org/10.1016/j.lwt.2018.11.047.

Giroux, H., N. Veillette, and M. Britten. 2018. Use of denatured whey protein in the production of artisanal cheeses from cow, goat and sheep milk. Small Rumin. Res. 161:34-42. https://doi.org/10 .1016/j.smallrumres.2018.02.006.

Haenlein, G. F. W. 2004. Goat milk in human nutrition. Small Rumin. Res. 51:155-163. https://doi.org/10.1016/j.smallrumres.2003 .08 .010 .

Havea, P., H. Singh, and L. K. Creamer. 2000. Formation of new protein structures in heated mixtures of BSA and alpha-lactalbumin. J. Agric. Food Chem. 48:1548-1556. https://doi.org/10.1021/ jf990736j.

Joyce, A. M., A. Brodkorb, A. L. Kelly, and J. A. O'Mahony. 2017. Separation of the effects of denaturation and aggregation on wheycasein protein interactions during the manufacture of a model infant formula. Dairy Sci. Technol. 96:787-806. https://doi.org/10 .1007/s13594-016-0303-4.

Kalyankar, S. D., C. D. Khedkar, and A. M. Patil. 2016. Goat: Milk. Pages 256-260 in Encyclopedia of Food \& Health. Elsevier Inc., Amsterdam, the Netherlands.

Khem, S., V. Bansal, D. Small, and B. May. 2016. Comparative influence of $\mathrm{pH}$ and heat on whey protein isolate in protecting Lactobacillus plantarum A17 during spray drying. Food Hydrocolloids 54:192-169.

Kim, D. A., M. Cornec, and G. Narsimhan. 2005. Effect of thermal treatment on interfacial properties of $\beta$-lactoglobulin. J. Colloid Interface Sci. 285:100-109. https://doi.org/10.1016/j.jcis.2004.10 .044 .

Lamb, A., F. Payne, Y. L. Xiong, and M. Castillo. 2013. Optical backscatter method for determining thermal denaturation of $\beta$-lactoglobulin and other whey proteins in milk. J. Dairy Sci. 96:1356-1365. https://doi.org/10.3168/jds.2012-5791.

Lee, S. Y., C. V. Morr, and E. Y. W. Ha. 1992. Structural and functional properties of caseinate and whey protein isolate as affected by temperature and pH. J. Food Sci. 57:1210-1229. https://doi .org/10.1111/j.1365-2621.1992.tb11301.x.
Li, Q., Y. Ma, S. He, W. Elfalleh, W. Xu, J. Wang, and L. Qiu. 2014a. Effect of $\mathrm{pH}$ on heat stability of yak milk protein. Int. Dairy J. 35:102-105. https://doi.org/10.1016/j.idairyj.2013.10.015.

Li, Q., Y. Ma, S. He, and R. Wang. 2014b. The compositional factors involved in the heat stable sensitivity of yak milk. RSC Advances 4:37669-37673. https://doi.org/10.1039/C4RA03600J.

McKinnon, I. R., S. E. Yap, M. A. Augustin, and Y. Hemar. 2009. Diffusing-wave spectroscopy investigation of heated reconstituted skim milks containing calcium chloride. Food Hydrocoll. 23:11271133. https://doi.org/10.1016/j.foodhyd.2008.08.009.

McSweeney, S. L., D. M. Mulvihill, and D. M. O'Callaghan. 2004. The influence of $\mathrm{pH}$ on the heat-induced aggregation of model milk protein ingredient systems and model infant formula emulsions stabilized by milk protein ingredients. Food Hydrocoll. 18:109-125. https://doi.org/10.1016/S0268-005X(03)00049-3.

Millqvist-Fureby, A., U. Elofsson, and B. Bergenståhl. 2001. Surface composition of spray-dried milk protein-stabilised emulsions in relation to pre-heat treatment of proteins. Colloids Surf. B Biointerfaces 21:47-58. https://doi.org/10.1016/S0927-7765(01)00183-7.

Moatsou, G. A. Hatzinaki, M. Samolada, and E. Anifantakis. 2005. Major whey proteins in ovine and caprine acid wheys from indigenous Greek breeds. Int. Dairy J. 15:123-131. https://doi.org/10 .1016/j.idairyj.2004.06.005.

Montilla, A., E. Balcones, A. Olano, and M. M. Calvo. 1995. Influence of heat treatments on whey protein denaturation and rennet clotting properties of cow's and goat's milk. J. Agric. Food Chem. 43:1908-1911. https://doi.org/10.1021/jf00055a028.

Morgan, F., S. Micault, and J. Fauquant. 2001. Combined effect of whey protein and $\mathrm{a}_{\mathrm{S}_{1}}$-casein genotype on the heat stability of goat milk. Int. J. Dairy Technol. 54:64-68. https://doi.org/10.1046/j .1471-0307.2001.00002.x.

Nicorescu, I., C. Loisel, C. Vial, A. Riaublanc, G. Djelveh, G. Cuvelier, and J. Legrand. 2008. Combined effect of dynamic heat treatment and ionic strength on the properties of whey protein foams - Part II. Food Res. Int. 41:980-988. https://doi.org/10.1016/j.foodres 2008.08.003.

Palmquist, D. L., and T. C. Jenkins. 2003. Challenges with fats and fatty acid methods. J. Anim. Sci. 81:3250-3254. https://doi.org/ 10.2527/2003.81123250x.

Parks, D. J., and M. R. Player. 2007. Alpha-helix mimetics: Progress toward effective modulation of protein-protein complexes. Frontiers in Drug Design \& Discovery: Structure-Based Drug Design in the 21st Century 3:5-44.

Partschefeld, C., U. Schwarzenbolz, S. Richter, and T. Henle. 2007. Crosslinking of casein by microbial transglutaminase and its resulting influence on the stability of micelle structure. Biotechnol. J. 2:456-461. https://doi.org/10.1002/biot.200600232.

Pearce, K. N., and J. E. Kinsella. 1978. Emulsifying properties of proteins: Evaluation of a turbidimetric technique. J. Agric. Food Chem. 26:716-723. https://doi.org/10.1021/jf60217a041.

Permyakov, E. A., and L. J. Berliner. 2000. $\alpha$-Lactalbumin: Structure and function. FEBS Lett. 473:269-274. https://doi.org/10.1016/ S0014-5793(00)01546-5.

Qi, P. X., D. Ren, Y. Xiao, and P. M. Tomasula. 2015. Effect of homogenization and pasteurization on the structure and stability of whey protein in milk. J. Dairy Sci. 98:2884-2897. https://doi.org/ 10.3168/jds.2014-8920.

Recio, I., M. L. Pérez-Rodríguez, L. Amigo, and M. Ramos. 1997. Study of the polymorphism of caprine milk caseins by capillary electrophoresis. J. Dairy Res. 64:515-523. https://doi.org/10 .1017/S0022029997002343.

Richert, S. H., C. V. Morr, and C. M. Cooney. 1974. Effect of heat and other factors upon foaming properties of whey protein concentrates. J. Food Sci. 39:42-48. https://doi.org/10.1111/j.1365-2621 .1974.tb00983.x.

Ruffin, E., T. Schmit, G. Lafitte, J.-M. Dollat, and O. Chambin. 2014. The impact of whey protein preheating on the properties of emulsion gel bead. Food Chem. 151:324-332. https://doi.org/10.1016/ j.foodchem.2013.11.071.

Ryan, K. N., Q. Zhong, and E. A. Foegeding. 2013. Use of whey protein soluble aggregates for thermal stability-A hypothesis paper. 
J. Food Sci. 78:R1105-R1115. https://doi.org/10.1111/1750-3841 .12207 .

Sharma, S. K., and D. G. Dalgleish. 1993. Interactions between milk serum proteins and synthetic fat globule membrane during heating of homogenized whole milk. J. Agric. Food Chem. 41:1407-1412. https://doi.org/10.1021/jf00033a011.

Shimo, S. P., X. Y. Wu, X. Z. Ding, X. Lin, and Y. Ping. 2015. The influence of heat treatment in liquid whey at various $\mathrm{pH}$ on immunoglobulin G and lactoferrin from yak and cows' colostrum/ milk. J. Food Processing Technol. 6:503. https://doi.org/10.4172/ 2157-7110.1000503.

Sun, Y., J. Chen, S. Zhang, H. Li, L. Jing, L. Lu, H. Uluko, Y. Su, W. Cui, and W. Ge. 2014. Effect of power ultrasound pre-treatment on the physical and functional properties of reconstituted milk protein concentrate. J. Food Eng. 124:11-18. https://doi.org/10 .1016/j.jfoodeng.2013.09.013.

Vasbinder, A. J., and C. G. de Kruif. 2003. Casein-whey protein interactions in heated milk: The influence of pH. Int. Dairy J. 13:669677. https://doi.org/10.1016/S0958-6946(03)00120-1.

Wijayanti, H. B., N. Bansal, and H. C. Deeth. 2014. Stability of whey proteins during thermal processing: A review. Compr. Rev. Food Sci. Food Saf. 13:1235-1251. https://doi.org/10.1111/1541-4337 .12105

Xu, W., S. He, Y. Ma, Y. Zhang, and R. Wang. 2015. Effect of the heat-induced whey proteins/ $\kappa$-casein complex on the acid gelation of yak milk. RSC Advances 5:8952-8956. https://doi.org/10.1039/ C4RA14432E.

Yang, M., W. Zhang, P. Wen, Y. Zhang, and Q. Liang. 2014. Heat stability of yak micellar casein as affected by heat treatment temperature and duration. Dairy Sci. Technol. 5:469-481. https://doi .org/10.1007/s13594-014-0173-6.

Yuksel, Z., E. Avcı, B. Uymaz, and Y. K. Erdem. 2012. General composition and protein surface hydrophobicity of goat, sheep and cow milk in the region of Mount Ida. Small Rumin. Res. 106:137-144. https://doi.org/10.1016/j.smallrumres.2012.03.022.

Zhang, Z., V. Arrighi, L. Campbell, J. Lonchamp, and S. R. Euston. 2016. Properties of partially denatured whey protein products: Formation and characterisation of structure. Food Hydrocoll. 52:95-105. https://doi.org/10.1016/j.foodhyd.2015.06.009.

\section{ORCIDS}

Xuan Zhao ๑ https://orcid.org/0000-0002-4615-4975

Xiangying Li •

Di Chen () https://orcid.org/0000-0001-9866-6318

Cunfang Wang @ https://orcid.org/0000-0001-7992-6524 